\title{
NIILISMO E ÉTICA: NOTAS SOBRE DERRIDA E NANCY
}

\author{
Rossano Pecoraro
}

RESUMO - Este artigo pretende investigar algumas dimensões da filosofia de Jacques Derrida e Jean-Luc Nancy em relação aos temas do niilismo, da ética e da política.

PALAVRAS-CHAVE - Niilismo. Ética. Filosofia política. Filosofia francesa.
ABSTRACT - This article aims to investigate some dimensions of Jacques Derrida's and JeanLuc Nancy's philosophy in reference to the themes of nihilism, ethics and politics.

KEY WORDS - Nihilism. Ethics. Political Philosophy. French Philosophy.

\section{Introdução}

Não é um exagero nem uma imprecisão afirmar que a filosofia dos últimos quarenta anos pode ser determinada por uma questão muito definida, embora nem sempre reconhecida ou aceita nos seus significados mais profundos e epocais: o niilismo e o seu ultrapassamento. ${ }^{1}$

A crise de fundamentos mina as certezas da filosofia e da ciência. O sentido se corrói. Os valores tradicionais se depreciam. Princípios e critérios absolutos se dissolvem. A vertigem subverte pensamento e ação. "Niilismo: falta a finalidade, falta a resposta ao 'porque'" escreveu Nietzsche em um fragmento de 1887. A cultura, a sociedade, as crenças, as instituições: tudo é sacudido, posto radicalmente em discussão. A superfície, antes congelada, das verdades e dos valores tradicionais está despedaçada e se torna difícil prosseguir o caminho. É o niilismo.

\footnotetext{
PUC-Rio.

Para uma introdução a esta temática Cf. entre outros: F. Volpi, Il Nichilismo, Roma-Bari, Laterza, 2004 (segunda edição atualizada. Da primeira edição existe uma tradução não integral publicada em 1999 pelas Edições Loyola com o título O niilismo); F. Vercellone, Introduzione a "Il nichilismo", Roma-Bari, Laterza, 2001; VV.AA., Traversées du nihilisme (Orgs: G. Leyenberger e J.J.Forte), Paris, Osiris, 1993; VV. AA. Nichilismo e politica (Orgs: R. Esposito, C. Galli, V. Vitiello), Roma-Bari, Laterza, 2000; Nietzsche et le temps des nihilismes (Org: J.F. Mattei), Paris, PUF, 2005; V. Verra, "Nichilismo", in: Enciclopedia del Novecento, Roma: IEI, volume IV, 1979; E. Jünger-M. Heidegger, Über die Linie (tr. it. Oltre la linea, Milão, Adelphi, 1989; G. Vattimo, O fim da modernidade. Niilismo e hermenêutica na cultura pós-moderna", São Paulo, Martins Fontes, 1996; IDEM, As aventuras da diferença. O que significa pensar depois Nietzsche e Heidegger, Lisboa, Edições 70, 1988. A. Caracciolo, Pensiero contemporaneo e nichilismo, Napoli, Guida, 1976; R. Ávila, El desafío del nihilismo, Madrid, Trotta, 2005; R. Pecoraro, Nilismo, Rio de Janeiro, Zahar Editor, 2007.
}

\begin{tabular}{|l|l|l|l|l|l|}
\hline VERITAS & Porto Alegre & v. 52 & n. 2 & Junho 2007 & p. 128-139 \\
\hline
\end{tabular}


Conceito essencial, imprescindível para compreender o pensamento contemporâneo. Signo do nosso tempo, fenômeno ubíquo, complexo, multifacetado, ao mesmo tempo causa, patologia e oportunidade. De maneira geral é possível considerar o niilismo: 1) como movimento "positivo" - quando, através de um labor de crítica e desmascaramento nos revela a ausência de cada fundamento, verdade, critério absoluto e universal e, portanto, convoca-nos diante da nossa própria liberdade e responsabilidade, agora não mais garantidas nem sufocadas ou controladas por nada; 2) como movimento "negativo" - quando, a acentuar-se nessa dinâmica de crítica e desmascaramento, são os traços iconoclastas e destruidores, os momentos do declínio, da paralisia e do ressentimento, as invocações do "tudo-vale" e do perigoso silogismo: se Deus (a verdade, o princípio) está morto, então tudo é permitido.

Uma vez esboçado o horizonte teórico da nossa investigação torna-se possível expor alguns elementos do trabalho filosófico de Jacques Derrida e Jean-Luc Nancy. O nosso propósito é mostrar tanto a maneira com a qual se confrontaram com a crise, como as "posições" ético-políticas que elaboraram para rebater os seus desafios e as suas injunções.

\section{$\S 1$}

Jacques Derrida: título por precisar. O relampejo, aqui, de um rastro traçado dez anos antes da queda do muro de Berlim² é uma mossa iniziale, um modo de começar indecidível diante de uma obra monumental, polêmica, ambígua, aporética, desmascaradora e messiânica, construtiva e desconstrutiva, niilista e transcendental. Os "quase-conceitos" forjados nas últimas quatro décadas do século XX por Derrida constituem um sistema de pensamento ${ }^{3}$ tão vasto quanto complexo. A quantidade de estudos sobre ele é imensa e a sua origem vária e disseminada: filosofia, psicanálise, literatura, teologia, arte, arquitetura, direito, ciências sociais. Teremos, pois, de delimitar a nossa esfera de intervenção, concentrandonos em alguns elementos - estritamente filosóficos - do trabalho de Derrida sempre orientado por um duplo movimento cuja dinâmica eversiva (e contra-eversiva) forma a "origem" das várias e diferentes feições - da interpretação cuidadosa à emulação, do reconhecimento à rejeição - que constituem a história da crítica. Neste sentido, talvez seja esta lava, nem tanto subterrânea, que solidifica os seus textos em uma (meta) trama unitária, em um "quadro d'insieme, ou texto, dentro

"Titre à préciser" é o título de uma conferência de Jacques Derrida proferida em 1979 e sucessivamente publicada em Parages, Galilée, Paris, 1986.

Escreve Derrida: "Se por 'sistema' se entende uma espécie de consequiência, de coerência, de insistência - um certo recolhimento -, há uma injunção ao sistema à qual nunca pude, nem quis, renunciar. Atesta-o a recorrência (...) de motivos, de referências de um texto para outro, malgrado a variedade das ocasiões e dos pretextos. Quanto pude escrever ao longo destes últimos trinta anos foi guiado por uma certa insistência que outros poderão achar também muito monótona" (Jacques Derrida-Maurizio Ferraris, Il gusto del segreto, Roma-Bari, Laterza, 1997, p. 5). 
do qual a reflexão de Derrida [...], desde os seus primeiríssimos trabalhos, se mo$\mathrm{ve}^{\prime \prime}{ }^{4}$

Ora, o niilismo é um hóspede incômodo na obra derridiana e, ao contrário da miríade de termos, conceitos, categorias, experiências, gêneros, etc., que a povoam, nunca enfrentado de forma explícita. Por quê? "Fundamento" de todo ato de escritura, pressuposto diferencial e, portanto, elemento que dispensa todo tipo de exame? Pretenso e superestimado fio condutor de uma época que não merece particular atenção e que é preciso desmistificar e ignorar? Nenhuma das duas hipóteses é satisfatória. De todo modo, é possível considerar o duplo movimento derridiano profunda e radicalmente niilista, ao menos no sentido do niilismo "positivo", consumado ou perfeito de que fala Nietzsche. É quando nada curioso, apenas para dar um exemplo (mas os nomes próprios poderiam multiplicar-se), que Silvano Petrosino, um dos maiores interlocutores e leitores de Derrida, sinta a necessidade de afirmar - desde o começo, à guisa de princípio - que a "filosofia derridiana não é reduzível a uma forma de problematicismo nem tampouco a uma espécie de elogio da ausência, do negativo, do efêmero, etc., e que, portanto, não pode ser classificada, como aconteceu com muita freqüência [...], como uma expressão do tão conclamado niilismo e/ou ceticismo contemporâneos". . Deve haver, evidentemente, um equívoco, uma desconsideração, um parti pris, pois a reflexão de Derrida - insistamos - é uma das maiores filosofias niilistas dos últimos dois séculos. Neste horizonte o essencial é, portanto, expor [colocar em perigo, arriscar e explicar, interpretar] alguns dos elementos mais significativos da economia geral e sem reservas da escritura derridiana.

A História, o sentido, os grands récits, antes de tudo. O niilismo acelerou a desertificação desses terrenos, abrindo espaço para a efetivação de novas tentativas de repensá-los fora dos esquemas e das categorias da tradição: "Do que se deve desconfiar, repito, é do conceito metafísico de história. É do conceito de história como história do sentido [...] se produzindo, se desenvolvendo, se realizando. Linearmente [...]: em linha reta ou circular". ${ }^{6}$ No conhecido Colóquio de Cluny (1970), dedicado à relação entre literatura e ideologias, o pensamento de Derrida foi citado, questionado, criticado. Com o propósito de "esclarecer certos mal-entendidos" e "fazer as coisas avançar um pouco mais", o filósofo discute com Jean-Luis Houdebine e Guy Scarpetta na terceira, e talvez mais importante entrevista, que compõe Positions (1972). À observação de Christine Glucksmann, que lhe objeta a construção de uma concepção de história demasiado linear, uma história como história do sentido, que parece cancelar a luta entre forças contrapostas (neste caso idealismo e materialismo), Derrida responde:

Será preciso lembrar que foi precisamente contra a autoridade do sentido - do sentido como significado transcendental ou como telos, em outras palavras, da história deter-

PETROSINO, S. Jacques Derrida e la legge del possibile. Un'introduzione, Milano: Jaca Book, 1997 (segunda edição, ampliada, revista e atualizada), p. 22.

Ibid. p. 23.

DERRIDA, J. Posições, Belo Horizonte: Autêntica, 2001, p. 64. 
minada, em última instância, como história do sentido, história em sua representação logocêntrica, metafísica, idealista [...] e até mesmo nas marcas complexas que ela pode ter deixado no discurso heideggeriano - que tentei sistematizar, desde os primeiros textos que publiquei, a crítica desconstrutiva? Quanto a isso, não quero mesmo me estender, nem fornecer qualquer referência: o propósito que acabo de formular é legível a cada página. ${ }^{\text {? }}$

A metafísica, assim como um texto, é estruturada por contraposições binárias, dicotomias, conceitos opostos. Não é possível, segundo Derrida, tomar posição, estabelecer prioridades, transformar um desses termos em princípio ou fundamento da realidade. Nada pode funcionar como tal, uma vez que não há origem pura, simples presença, mas apenas contaminação e co-implicação indissolúvel e absolutamente indecidível. Não podemos nos decidir por um ou outro termo, ou conceito, das oposições binárias que estruturam a metafísica porque "toda vez que decidimos por um, decidimos também pelo outro, automaticamente". ${ }^{8}$ É impossível indicar, pôr um fundamento, um sentido; fundar a realidade em um princípio único e supremo. O forte impacto niilista dessa posição é evidente. Deve ser sublinhado, de resto, que são as oposições da tradição metafísica a constituírem o solo e o alvo teorético e prático da desconstrução; são elas (nos vários âmbitos em que operam: político, ético, teorético, psicanalítico, etc., no texto, em suma) que a provocam, a desafiam, a instigam. Na primeira "fase" do seu trabalho (do fim dos anos sessenta até a queda do muro de Berlim, em 1989), Derrida se exercita na desmontagem dos textos filosóficos para fazer vir à luz todo o removido, os recalques, os brancos; principalmente o recalque do rastro que está na origem das contraposições das quais eles se alimentam. Opera-se a partir dos casos para alcançar as categorias; é uma psicanálise da metafísica (e dos textos) em que se revelam as suas doenças, as suas neuroses, os recalques que sustentam a sua própria auto-afirmação. É “a desconstrução como análise interminável'”, escreve Maurizio Ferraris. Um duplo movimento "em que construção e desconstrução são o deve e o haver de uma mesma escrituração comercial". "

Trata-se, em primeiro lugar, de tematizar o recalque subjacente, não apenas na constituição da subjetividade, como na história da metafísica; em seguida, será a prática da desconstrução a evidenciar o recalque mediante uma análise que não resultará na proposta de algum dado não-negativo, mas sim esclarecerá aquilo que constitui a "gênese da estrutura" e que delineia a "natureza dialética da subjetividade nas suas relações com o objeto", ou seja, a diferança (différance). Nesse processo, a atitude psicanalítica interage com os ensinamentos de Nietzsche sobre a "verdade" e com os outros dois "mestres da suspeita", segundo a conhecida definição de Paul Ricoeur, isto é, Marx e Freud. A idéia é que a filosofia não deve só desvelar os enganos provindos da realidade externa, como engajar-se em uma

\footnotetext{
Ibid. p. 56-57.

TARIZZO, D. Il pensiero libero. La filosofia francese dopo lo strutturalismo, Milano, Cortina Editore, 2003, p. 77 (o capítulo intitula-se: "A 'salvação' de Derrida").

FERRARIS, M. Introduzione a Derrida, Roma-Bari, Laterza, 2003, p. 68.
} 
obra de desmistificação e desmascaramento dos nossos auto-enganos; dos recalques, das pretensões, dos brancos, das auto-ilusões do "sujeito" (ou do "autor" do texto), antes de tudo a ilusão, a idéia cartesiana, metafísica, de um eu forte, autofundado, autônomo, sempre presente a si.

A desconstrução não desenvolve nem propõe teorias ou fundações; apenas mostra conexões, corrói as certezas de cada dicotomia, revela pontos de suspensão e molduras, margens. Não só trabalha com a inversão das oposições (gesto clássico da tradição metafísica), como, a um só tempo, evitando a cristalização de um novo conceito, opera um deslocamento, uma transgressão, uma expropriação. "Duplo gesto, dupla estratificação", diz Derrida em Posições; um "duplo registro", uma "dupla ciência" que não desacredita, mas insiste no momento da inversão, já que em toda oposição filosófica não se dá uma coexistência pacífica, mas sim um embate, um conflito, uma violência originária que se revela diante da decisão ou im-posição de uma primazia também axiológica, isto é, uma primazia de valores morais. ${ }^{10}$ É preciso, por um lado, intervir na hierarquia, inverter todo conceito tradicional, e, por outro, "ao mesmo tempo marcar a distância, cuidar para que ele não possa ser - em razão da inversão e pelo simples fato da conceptualização reapropriado". ${ }^{11}$ Ainda: a desconstrução não é tão-somente uma crítica ou uma destruição; é uma "obra de amor", sublinha John Caputo, na qual "o famoso 'a' da différance é uma letra amorosa (a love letter), não um alfa-privativo mas um alfaamoroso" ${ }^{12}$ é uma operação de destruição mediante a reconstrução dos equilíbrios, da arquitetura, dos "direitos" do texto.

Poder-se-ia dizer que, na verdade, ela não destrói nada, limitando-se apenas a dissolver aparências, isto é, todo princípio, presença, origem, fundamento filosófico ou metafísico que se impõe ao texto. O labor da diferança (différance) é essencial. Derrida dedica a esse "quase-conceito" um único texto que, lido em 1968, por ocasião de um congresso, foi sucessivamente inserido em Margens da filosofia. A diferança é diferenciar e diferir, é espaçamento temporal e também espaçamento espacial. É um movimento (genético-diferencial) ativo-passivo de produção de diferenças mediante o diferir, o adiar, o manter em reserva. Ela, porém, não se dá, não é presença, nem ausência nem presença modificada; deixa rastros, todavia não está nem ali nem algures, não tem lugar mas "gera" todos os lugares. Surge a sombra de um (novo) transcendental, entrevê-se, talvez, a possibilidade de sair do niilismo. A questão, porém, é muito mais complexa e menos entregue à ingenuidade do que parece.

Recomecemos, pois. O trabalho derridiano torna-se objeto de uma simples, mas não por isso menos grave e ameaçadora, objeção, ou seja, a diferança, a desconstrução não se tornam um novo fundamento (Grund)? Não se elabora uma

10 Cf., entre outros, "La double séance", in: La dissémination, Paris, Seuil, 1972; "La différance" e "Ousia et grammè. Note sur une note de Sein und Zeit" ambos reproduzidos em Marges de la philosophie (1972), tr. port: Margens da filosofia, Campinas,Papirus, 1991.

11 DERRIDA, J. Posições, p. 66

12 CAPUTO, J. "Por amor às coisas mesmas: o hiper-realismo de Derrida". In: Às margens. A propósito de Derrida, Editora PUC-Rio/Edições Loyola, Rio de Janeiro-São Paulo, 2002, p. 46. 
metafísica do texto? Não se recai na antiga tentação de indicar o mundo verdadeiro que estaria atrás do mundo aparente? E uma vez que "a única proposta possível na ótica desconstrucionista é uma metafísica do texto" é evidente que a objeção alcança um ponto decisivo, pois mostra a sua "falta de propostas positivas". ${ }^{13}$ De um ponto de vista político e ético o impasse revela-se ainda mais grave: Derrida, escreve Manlio Iofrida, permanece preso a "um dualismo 'cartesiano' de sentido e não-sentido", atesta que a racionalidade é uma só (ocidental, grega) e que ela pode e deve ser criticada mas sem propor uma transformação sua. O que se pode fazer é tão-somente criticá-la, "mostrando os seus paradoxos, as suas contradições, os seus limites [...] O logos pode ser de alguma forma enganado, eludido, posto em contradição consigo mesmo, pode-se revelar a sua paradoxalidade, mas não se pode mudar de maneira alguma a estrutura". ${ }^{14}$ A conclusão de Iofrida é que, desse modo, se profere um definitivo adeus a qualquer tipo de alternativa reformadora, a todo esforço de transformação social, ética, política. É evidente: essas críticas atingem o coração da obra derridiana, isto é, põem a nu o seu intrínseco nilisismo.

Uma afronta impossível de suportar à qual Derrida, na última fase da sua reflexão, como veremos, reagirá com força. Entre as críticas devem ser lembradas aqui, ao menos, as de Gianni Vattimo e Jean-Luc Marion, que insistem no conceito de différance. Em As aventuras da diferença (1980), ${ }^{15}$ o filósofo italiano acusa Derrida de não ter conseguido pensar a questão posta por Heidegger, de ter ficado insensível ao problema da diferença operando apenas uma sua absolutização que a neutraliza e a põe de lado. Idolatria ontoteológica, a diferança como conceito metafísico, que pertenceria ainda à metafísica do Ser sendo por ela definida e determinada: são estas as objeções de Marion avançadas em $O$ ídolo e a distância. ${ }^{16}$ Mas, o potente recalque de Derrida é o niilismo, não a metafísica. Por isso ele consegue rebater, de uma forma muito eficaz e convincente, essas críticas; em primeiro lugar, e de um modo geral, é impossível sair da metafísica; tentar ultrapassar uma época da qual entrevimos o fechamento mas não o fim; não dispomos de nenhuma linguagem, nenhuma sintaxe, nenhum instrumento que não esteja vinculado à metafísica, portanto é perfeitamente inútil nos jogar contra o círculo que delimita a nossa clausura: o resultado seria apenas, ainda, sempre já, uma substituição de fundamentos, que permite dominar a angústia que nos invade quando perdemos o centro. ${ }^{17}$ Nesse sentido, a différance não deixa de ser um "nome metafísico" (escrito, definido, pronunciado...), mas ela consegue escapar,

13 Cf. TARIZZO, D. Il pensiero libero. La filosofia francese dopo lo strutturalismo, p. 77-78.

4 IOFRIDA, M. "L'esaurimento del programma post-strutturalista: un bilancio e qualche prospettiva", in: Iride, ano XV, n⿳ 36, 2002, p. 274. Assinalamos que a crítica é dirigida também a Deleuze e Foucault; no final do ensaio Iofrida esboça uma perspectiva positiva na qual as referências teóricas são Adorno e Merleau-Ponty.

15 VATTIMO, G. As aventuras da diferença. O que significa pensar depois de Nietzsche e Heidegger, Edições 70, Lisboa, 1988.

16 MARION, J-L. L'idole et la distance, Paris, Grasset, 1977.

17 Cf. DERRIDA, J. La structure, le signe et le jeu dans le discours des sciences humaines. In: "A escritura e a diferença", São Paulo: Perspectiva, 1995. 
ou antes esquivar-se, das emboscadas metafísicas em virtude do seu caráter "histórico", ou seja, do labor silencioso e sem nome que ela exerce. Em outras palavras a diferança, não mais evocada, nomeada, apenas se mostra nas margens da filosofia, nos seus efeitos, no seu operar, no seu converter-se em obra e pôr-se em prática, no seu des-construir.

Ora, a grande afronta, enfim. Não apenas a metafísica, mas a acusação de niilismo, da total ausência de propostas positivas. Derrida sempre esteve ciente da seriedade da situação e da urgência de um contramovimento de sentido que, de resto, só se deu, como ele mesmo escreve em várias ocasiões, a partir dos eventos epocais de 1989. A co-implicação (dos termos ou conceitos do pensamento) e a indecidibilidade; os conceitos-limites, as antinomias como resultado da desconstrução: na última fase - ético-política - da sua reflexão, Derrida recusa e descontrói todas as soluções unilaterais nas quais se fundam as éticas contemporâneas, fazendo vir à luz as co-implicações, as aporias, o duplo vínculo [double bind, expressão que ele retoma de Gregory Bateson: ${ }^{18}$ contradição não-dialetizável e indecidível; "Insolubilidade e irresolução, economia do bind. Economia do vínculo ou da ligação", lê-se no ensaio sobre Freud publicado (1980) em La carte postale, de Socrate à Freud et au-delà] que as atravessa. Não renuncia nem remodela, portanto, os elementos cardeais do seu labor especulativo. Mas, se no plano teórico eles permitiam, quase obrigavam a não tomar decisão alguma, a inverter, deslocar, insistir nas margens, dialetizar, etc., no plano ético - do qual o filósofo decide aproximar-se para rebater (à sua maneira, é claro) as acusações de niilismo, ceticismo, ou negativismo - eles obrigam a decidir; e a impossibilidade de decidir - a aporia do decidir [sobre o outro, a hospitalidade, o acolhimento, a justiça, a amizade e a inimizade, o dom, o perdão, etc. $]^{19}$ - implica sempre o seu oposto, isto é, a necessidade de decidir. Uma vez desconstruída a desconstrução retorna-se, porém, à estaca zero. A única saída para Derrida é enfrentar o espectro que se relutava em enxergar: o "sujeito". ${ }^{20}$

Com efeito, quem decide? Quem padece a aporia da decisão? Quem permanece de contínuo na posição de ter de tomar uma decisão, triturado pela dúplice tenaz da impossibilidade e da necessidade de decidir? É Emmanuel Lévinas antes duramente criticado pela violenta e metafísica im-posição do Outro ${ }^{21}$ - a doar o tempo e a solução a Derrida: o "conceito" de testemunho. Mas a aporia

18 Cf. ZOLLETTO, D., Il doppio legame. Bateson e Derrida, Milano, Bompiani, 2003.

9 Entre os textos dedicados a estas questões devem ser ao menos assinalados: Psyché. Inventions de l'autre, Paris,Galilée, 1987; Donner le temps, Paris,Galilée, 1996; L'autre cap, Paris, Minuit, 1991; Sauf le nom, Paris, Galilée, 1993; Spectres de Marx, Paris,Galilée, 1993; Force de loi, Paris, Galilée, 1994; Politiques de l'amitié, Paris, Galilée, 1994; Adieu à Emmanuel Levinas, Paris, Galilée, 1996; Apories, Paris, Galilée, 1996; Donner la mort, Paris, Galilée, 1999.

20 A insistência nesta saída, nesta necessária volta ao "sujeito" é a hipótese central do livro de Tarizzo já citado.

21 Cf. DERRIDA, J. "Violence et métaphysique, essai sur la pensée d’Emmanuel Levinas" (1964), sucessivamente inserido em L'écriture et la différence, Paris: Seuil, 1967. 
(ética) da decisão atinge também a testemunha, cujo testemunho, secreto, ${ }^{22}$ é exatamente sobre a impossibilidade e a necessidade de decidir e que ela - junto com outros rastros, tais como o messianismo, a espera, o tudo por vir (a democracia, o estado, a justiça, a salvação, etc.) - consente a Derrida afastar de si e da sua obra os ventos do deserto niliista, abarcar certo otimismo moderno (em Il gusto del segreto, de 1997, definiu o seu sistema como "um leibnizianismo sem deus", vale dizer, uma biblioteca (lugar não-lugar) sem bibliotecário) e livrar-se finalmente da imagem (recalcada) tracejada por Lévinas em $1976,{ }^{23}$ do trabalho da desconstrução como a avançada das tropas nazistas na França que, ao retirar-se, deixa destruição e desolação. Agora, diante de nós... "un salut sans salvation, un salut juste à venir", ${ }^{44}$ como sentencia no livro dedicado ao pensamento de Jean-Luc Nancy.

\section{$\S 2$}

Uma filosofia por vir (à venir), uma filosofia finie, finita - no duplo sentido que chega ao termo, acaba e que é desde sempre acabada, terminada. A filosofia depois da filosofia (do niilismo, da metafísica, de Auschwitz e de Hiroshima, da dialética e do cartesianismo, etc.), que, problemática e criticamente, remete-se à "morte de Deus" de Nietzsche, ao "fim da filosofia" e à tarefa do pensamento de Heidegger e - sobretudo, talvez como signo decisivo de uma época - à desconstrução de Derrida. A filosofia da não-filosofia: uma filosofia finie, finita é "uma filosofia que 'está fora' da filosofia [...]. O dentro da filosofia é precisamente o seu fora". 25

Sentido, liberdade, localização do ser; o "com-", uma lógica da filosofia: é com estes conceitos - ou antes, experiências singulares plurais - que opera a reflexão de Nancy, uma das figuras mais importantes e originais do cenário filosófico contemporâneo em cerrado diálogo/confronto com o italiano Roberto Esposito. O pensamento: uma outra história, ou seja, um novo espaçamento. Não se trata mais, para Nancy, de "filosofia", isto é, de perceber pela visão, de refinar a vista, da veduta - para usar um termo italiano da história da arte - do mundo, do ser ou do sentido:

trata-se, antes, de abrir um espaço que inicialmente não é visível, de abrir um espaço para uma vista, ou um espaço de vista, que não será mais um espaço diante de um olhar. Se filosofar, então, teve no passado o significado de contemplar e fixar, hoje significa abrir os olhos, olhos que até agora ainda não foram abertos. Em outros termos: a filosofia, nos seus começos, foi o efeito de uma experiência inédita do mundo - inédita, fastidiosa, inquietante, excitante. E é essa realidade de experiência que ela reen-

22 Sobre o tema do "segredo" na obra de Derrida ver Jacques Derrida-Maurizio Ferraris, Il gusto del segreto.

23 LEVINAS, E. Noms propres, Montpellier, Fata Morgana, 1976.

24 DERridA, J. Le toucher, Jean-Luc Nancy, Paris, Galilée, 2000, p. 348.

25 ESPOSITO, R. "Dialogo sulla filosofia a venire" (com Jean-Luc Nancy), in: NANCY, J.-L., Essere singolare plurale, Torino, Einaudi, 2001, pp. VII-VIII. No escrito, que introduz a tradução italiana do livro de Nancy Être singulier pluriel (1996), Esposito refere-se também a Deleuze e Canguilhem. 
contra hoje. Talvez não se tenha desfeito dela nunca. Mas digamos que hoje ela não pode mais mascará-la o fazê-la preceder de algo outro, nem da própria história; pois, ao contrário, é exatamente desta história que ela deve refazer de novo a experiência. ${ }^{26}$

A filosofia funda-se no retrair-se dos deuses, isto é, no retrair-se da presença originária. É preciso compreender, com Nancy, que a definição de metafísica (de Nietzsche a Heidegger e Derrida) como "metafísica da presença" remete à "presença" que é uma ausência, um desaparecimento, o efeito de uma relação de perda com a presença (o sentido) "verdadeira", originária ou divina. Estamos, pois, sempre de luto; fincados no niilismo. Como sair dessa situação?

É sobre isto que é preciso abrir os olhos, olhos que até agora ainda não foram abertos, embora sejam talvez os mesmos olhos que se abrem em todas as épocas - ante cada nova época e cada novo dia - para configurar um mundo novo, um mundo inédito. Olhos para ver um sentido que não é mais o sentido que compreendíamos (que compreendíamos para afirmá-lo ou recusá-lo, sendo Hegel ou o seu contrário, que é ainda Hegel). Ou ouvidos... ${ }^{27}$

"O ser abandonado", título do ensaio que encerra o livro L'impératif catégorique (1983), é essencial para compreender o percurso filosófico de Nancy. A reflexão é propriamente ontológica; é sobre o sentido do ser, ou seja, sobre a localização do ser. Com a desconstrução da metafísica realizada por Heidegger e Derrida tornou-se evidente que a nomeação do ser é impossível. O ser (o sentido) não tem nome. Ele existe, localiza-se (Da-sein, estar-aí, ser-aí, être-là; há o ser, il y a, c’è). Como já sustentava Aristóteles, o ser se diz de muitas maneiras; ele é abandonado à multiplicidade dos seus nomes, das suas definições, e é abandonado pelo nome, pela idéia de ter um nome. Há um excesso, um sobejo, uma superabundância de ser, e não uma penúria. Mas o abandono, por sua vez, não deve ser compreendido como uma idéia (ou essência, fundamento, etc.) do ser, que o precipitaria novamente no círculo vicioso da tradição metafísica. Ao contrário: o ser é abandonado à multiplicidade das suas idéias, das suas definições entre as quais não é mais possível estabelecer hierarquia alguma. No abandono e na deriva o ser só pode ser localizado a cada vez como um certo ser-aí, um determinado estar aqui: há o ser, il y a, c'è.

O ser abandonado já começou a constituir, sem que nós o soubéssemos e sem que o pudéssemos saber, uma condição incontornável do nosso pensamento, e talvez até a sua única condição. A ontologia que exige de nós é uma ontologia para a qual o abandono é o único predicado do ser, ou o transcendental, no sentido escolástico da palavra. Se o ser continuou a se dizer em muitas maneiras - pollakos legetai - o abandono, porém, não acrescenta nada ao multiplicar do pollakos. Ele o resume, o recolhe, mas

\footnotetext{
${ }^{26}$ NANCY, J.-L. "Dialogo sulla filosofia a venire" (com Roberto Esposito). In: NANCY, J.-L., Essere singolare plurale, p. XI.
}

27 Ibid., p. XIV. 
exaurindo-o, levando-o à extrema pobreza do abandono. O ser se diz abandonado por todas as categorias e pelos transcendentais. ${ }^{28}$

Nancy fala explicitamente de lei, ou lógica (tanto do abandono, como da experiência, da liberdade, do partage) cuja aplicação a diferentes âmbitos e conceitos filosóficos caracteriza grande parte da sua reflexão. O ser é abandonado, é banido; a sua lei é não obedecer a lei alguma, não responder a e por nenhum nome, mas ser abandonado a cada lei e a cada nome. Por isso o ser não obedece nem à lei do abandono, pois esta deve ser entendida como o desaparecimento de toda lei do ser que, nu, é abandonado e exposto "ao rigor sem limite da lei". O abandono não é a obrigação de responder a ou por um ou alguns artigos de lei, mas sim obrigação de comparecer diante da lei, na sua totalidade: "a lei do abandono é o outro da lei, que faz a lei [...]. Deixar-se abandonar. E é isso que talvez signifique dizer, na extremidade das palavras, pensar". ${ }^{29} \mathrm{O}$ ser é abandonado a si próprio e, ao mesmo tempo, se descobre sem um $\mathrm{Si}$, sem um nome que o possua, o defina, o distinga, nem uma lei que o norteie. O ser não se possui, não tem soberania alguma sobre si, já que não tem um Si e ninguém pode invocar a soberania sobre o ser. O ser é a exceção fundadora da soberania, o fora-da-lei que funda a lei, que transforma cada nomeação do ser em uma lei, em uma legislação, um ato de soberania, sobre o ser abandonado.

Em 1986 é publicado La communauté déscauvrée, recebido com muitas reservas, desconfiança e até com hostilidade na Alemanha e na França (Derrida, Badiou, Lacoue-Labarthe) por causa do passado nazista e dos ecos autoritários do termo (e do conceito) "comunidade". Em verdade o propósito de Nancy era tentar afirmar o abandono da comunidade, delinear uma lógica da comunidade, expor a idéia "de uma comunidade que não converte em obra nenhuma comunidade". ${ }^{30} \mathrm{De}$ qualquer forma, é a partir destas controvérsias que o léxico do qual ele se servia desliza de contínuo "rumo ao 'estar-em-comum', ao 'estar-junto', ao 'compartilhamento' (partage), para chegar ao 'estar-com' ou ao puro e simples 'com', como se poderá ler em Ser singular plural [obra de 1996]". ."

"A existência é a essência de si mesma": esta simples definição está na base de A experiência da liberdade (1998) cujo argumento, como Nancy escreve na nota número 15 de Une pensée finie, "consiste no deslocar o conceito de 'liberdade' da autonormatividade de um Sujeito infinito para a exposição de um existente finito". No livro é formulada uma lógica da liberdade que logo parece um contra-senso, um paradoxo. Como é possível enjaular a liberdade (e a experiência) em uma lógica? Elas, que desafiam e se rebelam a qualquer lógica, não se anulariam ao se tornar calculáveis, previsíveis, determináveis? Nancy responde com uma lógica da surpresa, do imprevisível, do impossível (na qual ressoam traços derridianos): a

28 NANCY, J-L. L'impératif catégorique, Paris,Flammarion, 1983, p. 141.

Ibid., p. 149-150.

NANCY, J.-L. "Dialogo sulla filosofia a venire" (com Roberto Esposito). In: NANCY, J.-L., Essere

singolare plurale, op. cit., p. XX.

31 Ibid. 
liberdade é a liberdade da existência que, abandonada a si própria e abandonada por toda determinação e todo Ser, não possui nenhuma essência. Ela é o princípio, o sentido de si mesma. É a liberdade da existência da essência, uma existência imprevisível, que sempre já surpreende, e sobrevém a si mesma. É o cair sobre si do ser (o peso do ser, como diz Nancy). A liberdade não é, de forma alguma abstrata ou teórica, algo que possa ser dissecado, sistematizado, formulado uma vez por todas - em uma expressão: que possa transfigurar-se em ideo-logia. A liberdade se experimenta, apenas. A existência é a "experiência da liberdade da existência da essência". E quando essa experiência se traduz em palavras, o próprio dizer (a nossa liberdade) será também uma experiência. Uma experiência do pensamento.

No livro de 1990 Une pensée finie, Nancy enfrenta, de uma forma explícita, intensa e rica (fato pouco usual na filosofia contemporânea) a questão do sentido. É impossível examinar detalhadamente a exposição de Nancy, cuja perspectiva teorética logo se enxerta em reflexões ético-políticas das feições ainda por vir e, portanto, dificilmente definíveis. Será suficiente lembrar aqui a insistência de um duplo movimento, de uma preocupação antimetafísica e antiniilista, de uma experiência do sentido e do ser na liberdade, no abandono, na existência, na finitude. O pensamento não se ocupou com outra coisa a não ser com o sentido; ele sempre esteve ausente e nós sempre tivemos a experiência da sua falta. Mas "faltar de sentido, ser na indigência/necessidade do sentido, exatamente isto é o sentido. Poder-se-ia dizer assim: faltar de sentido, propriamente falando, é não ter falta de nada" ${ }^{32}$ Não se trata de abdicar ante 0

fascínio da falta (abismo, não lugar, luto, ausência) cuja necessidade permanece evidente para a história recente do pensamento, mas da qual não é menos evidente o risco de uma confusão dialético-niilista. E todavia 'não faltar de nada' (estar [ser] no sentido) nem sequer é a condição plena e satisfeita de uma essência. Aqui não está dissimulada uma teologia negativa. Falta de nada, malgrado tudo falte: tal é o existir. ${ }^{33}$

A finitude é a responsabilidade do sentido; a finitude é o com-partilhamento (partage) do sentido que se dá, tem lugar em cada existência do existir. É o que se pode chamar de liberdade: "A liberdade é o fato mesmo da existência enquanto aberta sobre o próprio existir, e este fato é o sentido [...]. O sentido é a liberdade, como sentido finie [acabado e finito], ou como infinito ausentar-se da apropriação do sentido. A 'liberdade' (se se deve manter este nome) é o ato da indigência/necessidade do sentido". ${ }^{34}$ A questão, agora, não é mais o sentido, o contrasenso, o insensato (e o luto, a nostalgia, o a-fundamento no negativo: "a morte de Deus - o aprendemos com a nossa própria história - é por definição não desfrutável. Toma-se consciência, e se pensa depois dela, e ponto final." ${ }^{35}$ mas sim 0

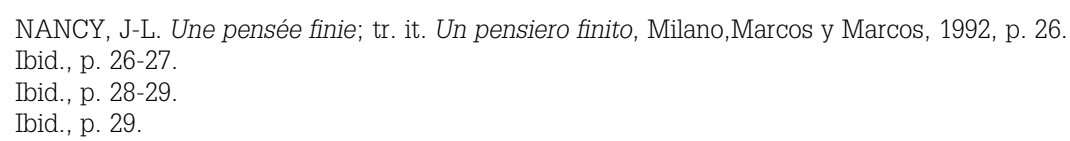


acesso ao sentido, o como entrar nele. A solução de Nancy - que pretende ser uma ética e uma ontologia política - reside no "com". Resumindo: a existência é o sentido de si mesma; e para conquistar o sentido do sentido é preciso compreender, por um lado, que "o próprio ser nos é dado como sentido", por outro, que "o sentido é ele próprio a repartição e o compartilhamento (partage) do ser". Não há um sentido único, último, fundador da existência; um único nome próprio do sentido. O sentido se localiza a cada vez em diferentes pontos (existências) singulares-e-plurais que, por sua vez, são fontes de sentido do ser. "Nós somos o sentido" escreve Nancy no capítulo homônimo que abre Être singulier pluriel; a existência é sempre uma co-existência. ${ }^{36}$

O ser é singular e plural, ao mesmo tempo, indistintamente e distintamente. Tudo isso não fornece um predicado particular do ser [...]. O singular-plural (ou o plural-singular) forma ao contrário a constituição de essência do ser: uma constituição que desfaz ou que desloca, por conseguinte, toda essência uma e substancial do próprio ser. De qualquer forma, tudo não é outra coisa senão uma maneira de dizer, pois não há nenhuma substância que possa ser dissolvida. O ser não preexiste de modo algum, nada preexiste: existe só o que existe [...]. O que existe, qualquer coisa que seja, do momento que existe, co-existe. A co-implicação do existir e o compartilhamento de um mundo [...]. Ser singular plural quer dizer: a essência do ser é, e é somente, uma coessência; mas uma co-essência, ou o ser-com [estar-com] - ser-em-tantos-com - designa por sua vez a essência do co-, ou melhor o co- (o cum) mesmo na posição ou à guisa de essência [...]. Se o ser é ser-com, no ser-com é o 'com' a fazer o ser, e não é acrescentado ao ser [...]. Não se trata de primeiro do ser ao qual se acrescenta o 'com', mas do 'com' no coração do ser. ${ }^{37}$

36 Deve ser assinalado o caráter programático do livro de Nancy, que não formula uma conclusão, mas expõe um percurso de pesquisa: repensar as condições de uma crítica da sociedade com base em uma ontologia do ser, do ser, obviamente, como singular-plural, como estar-com. Uma "ética originária" (titulo de um seu trabalho). Uma ética ontológica ou uma ontologia ética, como diz Esposito. Uma retomada do projeto ontológico de Heidegger no sentido de uma analítica da co-existência.

37 NANCY, J.-L. Essere singolare plurale, capítulo VI, p. 43-45. 